\title{
AN ANOMALY OF THE REPRODUCTIVE ORGANS IN TROCHULUS HISPIDUS (LINNAEUS, 1758) (GASTROPODA: PULMONATA: HYGROMIIDAE)
}

\author{
MAŁGORZATA ProćKÓW ${ }^{1}$, ELŻBIETA KuŹNIK-KOWALSKA ${ }^{2}$

\begin{abstract}
${ }^{1}$ Museum of Natural History, Wrocław University, Sienkiewicza 21, 50-335 Wrocław, Poland (e-mail: mprockow@biol.uni.wroc.pl)

${ }^{2}$ Department of Invertebrate Systematics and Ecology, Institute of Biology, Wrocław University of Environmental and Life Sciences, Kożuchowska 5b, 51-631 Wrocław, Poland
\end{abstract}

ABSTRACT: A specimen of Trochulus hispidus from Buchenbach, Germany, had its male and female parts of the reproductive system completely separated. The female part lacked auxiliary organs. The male part opened into the genital atrium, but the vas deferens was blind-ended in a way precluding sperm transfer.

KEY WORDS: land snail, Trochulus hispidus, Hygromiidae, reproductive organs, anomaly

Anomalies of the reproductive organs have been recorded in several species of pulmonate land snails. The vast majority involves the male part of the reproductive system, while female organs are usually normally developed. Repetition of the penis is the most common anomaly and has been reported in Helix pomatia Linnaeus, 1758 (PARAVICINI 1898, PÉGOT 1900, ASHWORTH 1907, LATTMANN 1967), Cernuella virgata (Da Costa, 1778) (HAUSDORF 1989), Mastus cf. cretensis (Pfeiffer, 1846) (MAASSEN 2000) and Rhynchotrochus albocarinatus (Smith, 1887) (JORDAENS et al. 2009). In Helix aspersa (O. F. Müller, 1774) the absence of the male reproductive organs has been observed (COLLINGE 1893). The only reported case of abnormal female organs pertains to Helix pomatia (SCHUBERTH 1892).

In this note we report on an individual of Trochulus hispidus (Linnaeus, 1758) from Buchenbach (Baden-Württemberg, Germany) with anomalies of both male and female organs. Moreover, some variations in dart sacs and mucous glands were observed in further four examined snails. The remaining three specimens from the same population showed no reproductive anomalies.

The examined snail was full-sized but its shell, with 5.5 whorls, had no lip or rib inside the aperture. The shell width was $7.2 \mathrm{~mm}$, height $3.6 \mathrm{~mm}$ and the size did not differ from the remaining specimens from that site. On dissection, we found the reproductive organs to be abnormal. Two separate parts could be distinguished. One was blind-ended and consisted of the gonad, the hermaphrodite duct, the albumen gland and the spermoviduct which passed into the short spermathecal duct ending with the spermatheca (Fig. 1A). It was completely isolated. No vagina or auxiliary organs, like mucous glands or dart sacs, were present. The other part comprised the penis opening to the genital atrium, the epiphallus and the flagellum. The penial retractor muscle was inserted in the usual position at the junction of the epiphallus and the penis (Fig. 1B). The vas deferens, seen in connection with the flagellum, was very short and inserted into the body wall (Fig. 1C).

While dissecting seven more specimens from this locality, a few other anomalies could be noticed. In one specimen one pair of dart sacs was normally developed whereas the other pair appeared to be represented by only one sac. However, a more detailed investigation showed that there were two sacs laying one behind another, but the upper one was very flat. Moreover, in the same individual variously developed mucous glands were observed. Their variation involved both the length and the shape. Among those digitiform glands there were some club-shaped or dis- 

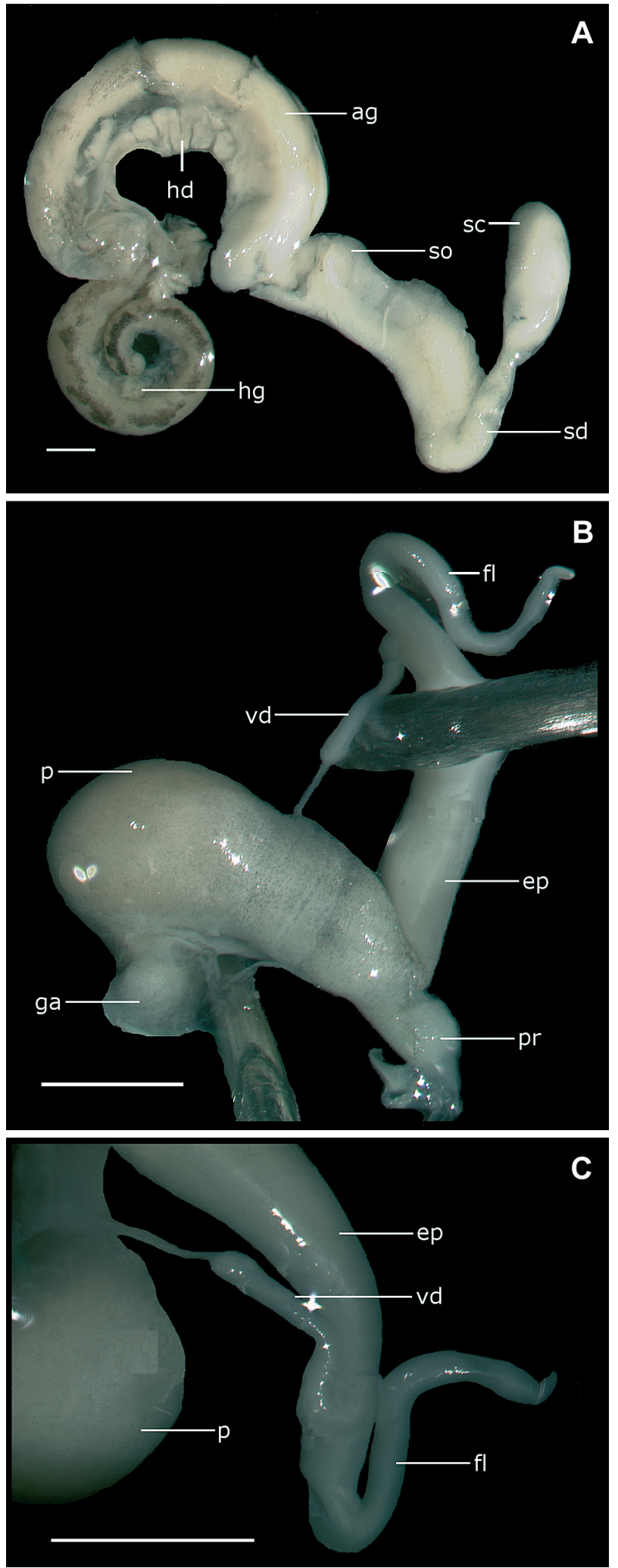

Fig. 1. Abnormal reproductive organs in a specimen of Trochulus hispidus from Buchenbach: A - isolated part; B male proximal genitalia; $\mathrm{C}$ - vas deferens inserted into body wall. Abbreviations: ag - albumen gland, ep - epiphallus, fl - flagellum, ga - genital atrium, hd - hermaphroditic duct, hg - hermaphroditic gland, p - penis, pr penial retractor, sc - spermatheca, sd - spermatheca duct, so - spermoviduct, vd - vas deferens. Scale bars $1 \mathrm{~mm}$ tally expanded glands, and their length ranged from $0.9 \mathrm{~mm}$ to $2.2 \mathrm{~mm}$. They were inserted to the vagina on one side, singly, or were divided into two unequal branches (Fig. 2). A similar variation of the mucous glands was observed in three more snails.

In $H$. pomatia, in the only recorded specimen with abnormal female reproductive organs, the oviduct was almost completely atrophied for a distance of 36 $\mathrm{mm}$ from the albumen gland, so that it was present above the prostate as a mere streak. The anterior portion of the oviduct was, however, fully developed (SCHUBERTH 1892). The case of T. hispidus was thoroughly different, the oviduct and the spermatheca were the only present female organs. Anyway, in both cases successful copulation as a female was completely impossible. Contrary to T. hispidus, H. pomatia could play a male role freely (SCHUBERTH 1892). On the other hand, in $M$. cf. cretensis and $R$. albocarinatus, in which the female organs were normally developed and connected with the genital atrium, copulation as a female should be possible, unless simultaneous reciprocal intromission of penes was necessary for successful copulation. However, since they had two penes and epiphalli connected with a single, short vas deferens that did not make contact with the spermoviduct, successful copulation as a male, was im-

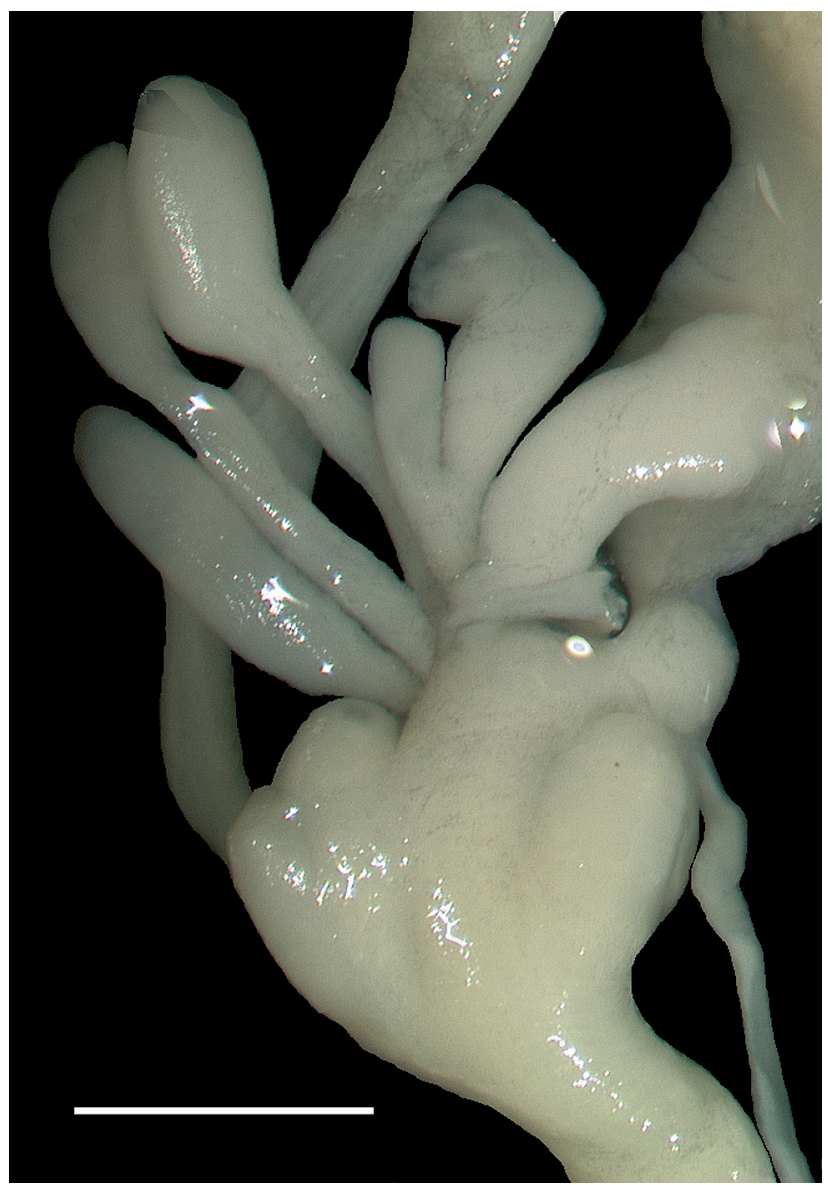

Fig. 2. Auxiliary organs in a specimen of Trochulus hispidus from Buchenbach. Scale bar $1 \mathrm{~mm}$ 
possible (JORDAENS et al. 2009). Copulation as a male and a female was prevented in C. virgata where only a blind-ending penis inserted at the genital atrium (HAUSDORF 1989). In H. pomatia, successful copulation as a male and a female, in theory, was possible but could be accompanied by practical difficulties (PÉGOT 1900).

There is a considerable variation of the reproductive organs of $T$. hispidus, in particular the number

\section{REFERENCES}

AshWORTH J. H. 1907. A specimen of Helix pomatia with paired male organs. Proc. Roy. Soc. Edinburgh 27: 312-331.

Collinge W. E. 1893. On the absence of the male reproductive organs in two hermaphrodite molluscs. J. Anat. Physiol. 27: 237-238.

HAUSDORF B. 1989. Über eine Anomalie der männlichen Endwege des Genitalsystems bei Cernuella virgata (Da Costa) (Gastropoda: Hygromiidae). Heldia 1: 175-176.

JORDAENS K., BRUYNDONCX L., GOETHEM J. VAN, BACKELJAU T. 2009. Morphological and anatomical differentiation of three land snails of the genus Rhynchotrochus (Gastropoda: Pulmonata: Camaenidae). J. Moll. Stud. 75: 1-8. doi: 10.1093/mollus/eyn035

LATTMANN P. 1967. Anomalie der männlichen Geschlechtsorgane bei Helix pomatia. Arch. Moll. 96: 143-144.

MAASSEN W. J. M. 2000. A separate duplicate penis in a specimen of Mastus (Gastropoda, Pulmonata, Buliminidae) from Greece. Basteria 64: 33-34.

NAGGS F. 1985. Some preliminary results of morphometric multivariate analysis of the Trichia (Pulmonata: Helicidae) species groups in Britain. J. Nat. Hist. 19: 1217-1230. doi: 10.1080/00222938500770771 and branching pattern of the mucous glands (WAGNER 1915, SHILEYKO 1978, PROĆKÓW 2009). Although they appear very distinctive in the species, they also vary widely in size and shape from one individual to another (NAGGS 1985). Thus, they cannot be used as a distinguishing character and the examined individuals confirm this observation.

PARAVICINI G. 1898. Organi genitali anomali nell' Helix pomatia. Boll. Scient. 20: 39-44.

PÉGot M. G. 1900. Observations sur la présence d'un triple appareil copulateur chez un Helix pomatia. C. R. Seances Soc. Biol. Fil. 52: 294-295.

ProćKów M. 2009. The genus Trochulus Chemnitz, 1786 (Gastropoda: Pulmonata: Hygromiidae) - a taxonomic revision. Folia Malacol. 17: 101-176. doi: 10.2478/v10125-009-0013-0

SCHUBERTH O. 1892. Beiträge vergleichenden Anatomie des Genitalapparates von Helix, mit besonderer Berücksichtigung der Systematik. Arch. Naturg. 58: 1-65.

SHILEYKO A. A. 1978. On the systematics of Trichia s. lat. (Pulmonata: Helicoidea: Hygromiidae). Malacologia 17: 1-56.

WAGNer A. J. 1915. Beiträge zur Anatomie und Systematik der Stylomatophoren aus dem Gebiete der Monarchie und der angrenzenden Balkanländer. Denkschr. Math.-Nat. Kl. Akad. Wiss. 91: 429-498.

Received: June 30th, 2011

Accepted: September 25th, 2011 